object to what would generally in the circumstances be a very real charity.

But lately a new idea has been started-viz., that of catering for the rich and moneyed classes, and by this means working up a profitable business-in other words, appropriating the funds devoted to charity for the satisfaction of the needs of the well-to-do and so crowding out the poor for whom they were originally provided. This opens a very important and serious consideration. These hospitals are beautifully equipped, far in advance of anything to be found in the ordinary medical or surgical homes that are established for the reception of the wealthier classes. Moreover, the acknowledged skill and capacity found there freely given is exceptionally costly to purchase elsewhere, so that persons in more modest circumstances who are quite able to pay moderate sums for what they require and who desire to have the advantage of the greatest skill they can obtain in the conduct of operative measures are naturally disposed to take advantage of the open hospital door. To a certain extent nursing homes are open to this class of cases but as a rule they miss the conveniences, the perfect sanitary arrangements, the resident medical officers, and the efficient control of every department of service that is to be found in the larger and bette equipped hospitals. They can have their own medical man and the consultant they select-of course a great point with many. In London and other large towns I daresay there are many suitable places of this kind, where members of the wealthier classes can be received and adequately dealt with, but for the lower grade the price is prohibitive. These nursing homes appear better suited for country places with a sparse population than for large towns. Why cannot the wealthy and all who are rich in this world's goods join together to produce for themselves and their neighbours and kinsfolk what they do for the poorest of the poor, start one as a pay hospital, sufficient in size for its probable requirements, with an adequate scale of resident staff, nursing efficiency, comfort, health, and perfect sanitation, and place it in every large town or great centre? It would be quite as legitimate for the operations of a company as the financing of hotels or hydropathic establishments, and with suitable tariffs arranged for different classes of occupants it would probably prove in the end a commercial success. A generous magnate, like Mr. Oarnegie, desirous to initiate good works with his surplus capital, could hardly find a better way of starting a great and most beneficent movement than by founding on thoroughly good lines a pay hospital in some large and populous central place, preserving to every patient the right to be looked after by his own medical man and his own consultant at his own expense if he so desires.

This type of hospital, once well started, would command extensive imitation and similar institutions would gradually grow up around in all our large towns and would relieve the other class of hospitals of numerous costly cases that would then have no right or occasion to go there. It might at first seem to be a hardship for those carrying on the nursing homes that a movement of this kind should be created which would very probably render their homes unremunerative; but many are now carried on under difficulties and a great change of this kind would open up many opportunities for employment for them, with less of pecuniary anxiety and responsibility. I would say in conclusion that the requirements of the surgery of the present day have been so entirely modified and enlarged by the great discoveries and improvements in recent times that what has been found to be essential and necessary to promote the recovery and well-doing of the poor man is equally as necessary as for the rich. Rich men have provided in the past most liberally and handsomely for the wants of the poor; will they not also now be persuaded to take this matter in hand and provide also for themselves, for their own kith and kin, and for their less wealthy brethren, a refuge for the future in their times of greatest agony and distress ? I am, Sirs, yours faithfully,

June 15th, 1906. SAMUEL KNAGGS.

\section{FOOD INSPECTION.}

To the Editors of THE LANCET.

SIRs, -Just now, when public attention is being directed to the question of the purity of food-supplies, it will probably be of interest to your readers to know something of what is being done with regard to the inspection of food sold in this country. Some seven years ago the report of the Royal Oommission on Tuberculosis made several suggestions with a view to securing the purity of the food-supply and recommended that in future no person be permitted to act as a meat inspector until be has passed a qualifying examination. These suggestions and recommendations were embodied in a circular issued by the Local Government Board to the local authorities throughout the country. Following on this report the Royal Sanitary Institute, in order to facilitate the carrying out of these suggestions, established special courses of instruction and examinations directed to the qualification of public officers whose particular duty was the inspection of meat and food. The examinations for inspectors of meat and other foods are held in the principal centres of England and have by special request been extended to colonies where other examinations are held by the institute.

The syllabus for this examination was submitted to, and in general terms approved by, the Local Government Board of Fingland, the Local Government Board of Scotland, and the Local Government Board of Ireland. The examination is made in every way as practical as possible and the candidates are examined on actual specimens of meat, fish, canned, and preserved foods. During the period that this examination has been held 280 candidates have come up for examination and 193 certificates have been granted. Many of those who have obtained certificates are now holding appointments in the principal towns and ports of the country. The President of the Local Government Board, in reply to a question in the House last week, called attention to the importance of efficient inspection of food-supplies and it is in order to make such inspection possible that the institute are urging the necessity of local authorities having for this purpose the assistance of competent and qualified officers. I am, Sirs, yours faithfully,

J. LAANE NOTTER, Chairman of Council. Royal Sanitary Institute, Margaret-street, London, $\mathbf{w}$. June 14th, 1906

\section{THE FIRST GARDEN CITY.}

\section{7o the Editors of THE LANCET.}

SIRS,-The Garden City Company has been now in existence over two years and $I$ think all those interested in the undertaking are pleased, and not a few of them surprised, at the progress which has been made towards the realisation of its object. That object was, as most of your readers are probably aware, to procure the building of an industrial and residential town on hygienic principles in accordance with the ideas promulgated by Mr. Ebenezer Howard in his book, "Garden Cities of To-morrow."

The company has acquired a site of over 3800 acres at Letchworth, near Hitchin. The Garden City bas its own station provided by the Great Northern Railway, factories are at work, gasworks and waterworks are in operation, about 150 acres of building sites have been let, over 400 houses are built or in course of building, and we have already a population of over 1600. This by itself is, I submit, not a bad record for two zears' work, but much has been accomplished in addition which $I$ must not trespass on your space to describe. Our progress would, however, have been much more rapid if we had had more capital at our command. In some instances accommodation might profitably have been provided both for manufacturers and their workpeople had the capital been available. There are, moreover, at least 300 men at the present moment working on the estate who desire to live on it but for whom no accommodation can be found and the time has arrived when we have decided to come to the public for further financial support to enable us to push on with our enterprise and to clear the estate from the mortgages which still affect it. The capital of the company is $\$ 300,000$, upon which the dividend is limited to 5 per cent. cumulative, all profit in excess going to the benefit of the town and its inhabitants. Of this about $£ 134,000$ have been allotted and the balance is being offered for public subscription.

Now, Sirs, there are multitudes of people of means in this country who are alarmed at the symptoms of physical degeneration exhibited by our town populations and who look to better housing and the redistribution of the people upon the land for remedy, and I am quite sure that they would not knowingly allow an enterprise such as ours to be 